\title{
Sistem Pengelolaan Arsip Surat Masuk Dan Keluar Berbasis Client Server Studi Kasus: SMK Negeri 1 MANDIRAJA
}

\author{
Abdul Azis*1, Riyanto ${ }^{2}$, Akto Hariawan ${ }^{3}$ \\ ${ }^{1,2,3}$ Universitas Amikom Purwokerto; Jl. Letd Jend Pol Sumarto, 0281 623321/0281 623196 of \\ Universitas Amikom Purwokerto \\ ${ }^{1,2,3}$ Sistem Informasi, Fakultas Ilmu Komputer, Universitas Amikom Purwokerto \\ e-mail: *1abdazis9@ amikompurwokerto.ac.id, ${ }^{2}$ riyanto@ amikompurwokerto.ac.id, \\ 3aktohariawan@amikompurwokerto.ac.id
}

\begin{abstract}
Abstrak
Arsip surat masuk dan surat keluar selama ini masih dilakukan secara konvensional berupa hard copy atau lembaran-lembaran kertas yang menyulitkan dalam hal pencarian jika sewaktu waktu dibutuhkan. Surat yang masuk beberapa tahun yang lalu tentu akan sulit dicari jika menggunakan cara penyimpanan berupa hard copy baik itu karena semakin menumpuknya arsip atau arsip surat yang sudah rusak. Kesulitan dan kerumitan tersebut dapat diatasi dengan membangun suatu sistem administrasi arsip surat yang lebih terstruktur agar dapat mempercepat pencarian data yang ada dan pembuatan laporan, sehingga penulis merasa perlu merancang Sistem Administrasi Pengelolaan Surat berbasis Client Server menggunakan bahasa pemrograman PHP dan database MySql. Metode pengumpulan data yang dipakai dalam penelitian ini adalah observasi, wawancara, dokumentasi dan studi pustaka. Metode pengembangan sistem yang digunakan adalah Extreme Proramming. Sistem Administrasi Pengelolaan Arsip surat ini dapat digunakan untuk mempermudah proses pencarian, pembuatan laporan dan pengelolaan arsip surat di SMK Negeri 1 Mandiraja.
\end{abstract}

Kata kunci-Client Server, Pengelolaan Surat, Extreme Programming

\begin{abstract}
Archive incoming and outgoing mail for this is still done conventionally in the form of hard copy or sheets of paper are difficult in terms of search at any time if needed. Incoming mail a few years ago would be difficult to find if usung hard-copy storage means either that because of the accumulated records orarchives because the letters that have been damaged. Difficulties and complexities can be overcome by building a more structured mail archive administration system so that it can speed up existing data searches and report generation, so the authors feel the need to design a Client Server-based Administration System Management using the PHP programming language and MySql database. Methods in collecting data in this research were observation, interview, literatur interview, and documentation. System development method used is Extreme Programming. Administration System Management of this mail archive can be used to simplify the process of searching, reporting and managing file records at Vocational High School Negeri 1 Mandiraja.
\end{abstract}

Keywords - Client Server, Management Mail, Extreme Programming 


\section{PENDAHULUAN}

$\mathrm{S}$ urat merupakan sarana penting dalam sebuah instansi pemerintah, termasuk pada SMK Negeri 1 Mandiraja, sehingga penting untuk dilakukan pengarsipan surat dan dokumentasi yang baik. Melalui Peraturan Menteri Pendidikan dan Kebudayaan Republik Indonesia Nomor 74 Tahun 2015 Tentang Pedoman tata naskah dinas di lingkungan kementrian pendidikan dan kebudayaan, pemerintah menghimbau pada semua instansi pemerintah di bawah kementrian pendidikan dan kebudayaan untuk menyusun tata naskah dinas elektronik yang mengacu pada panduan dalam peraturan tersebut [1].

Surat masuk dan surat keluar di SMK N 1 Mandiraja terdiri dari beberapa jenis, diantaranya adalah surat pemberitahuan, surat undangan, surat keterangan, surat perintah, surat permohonan, serta surat tugas, yang memerlukan pengarsipan yang baik. Dalam arsip juga terdapat pencatatan, penyimpanan, pengolahan tentang segala surat baik dalam pemerintahan maupun dalam soal umum, serta melingkupi tujuan surat ke dalam maupun keluar, dengan sistem tertentu yang dapat dipertanggung jawabkan [2].

Berdasarkan hasil wawancara yang telah dilakukan dengan salah satu pegawai tata usaha SMK Negeri 1 Mandiraja pengelolaan data yang di terapkan pada administrasi surat masuk dan surat keluar di bagian administrasi tata usaha SMK Negeri 1 Mandiraja mulai dari penerimaan, pembuatan, penyimpanan, pendokumentasian, hingga verifikasi surat, semua dilakukan secara konvensional. Penerapan metode tersebut, menjadikan manajemen surat masuk dan surat keluar di bagian administrasi tata usaha SMK Negeri 1 Mandiraja kurang efektif. Diantaranya adalah pencarian dokumen jika dibutuhkan kembali membutuhkan waktu lama dan sulit sebab harus membuka terlebih dahulu data-data lama dan mencarinya satu persatu, masalah lain dalam laporan surat masuk dan surat keluar yaitu hilangnya dokumen.

Dari beberapa permasalahan pengarsipan dan pemanfaatan komputer yang belum maksimal dan peneliti mengacu pada penelitian yang dilakukan [3] yang berjudul Aplikasi Sistem Kearsipan Surat - Surat Dinas menggunakan Elektronik Arsip (E- ARSIP) di Sekretariat Daerah Provinsi Jawa Tengah. penelitian tersebut menghasilkan aplikasi E-ARSIP menggunakan microsoft access. Dari penelitian tersebut peneliti bermaksud merancang sebuah sistem administrasi arsip surat masuk dan surat keluar berbasis client server yang menangani pengarsipan dengan lebih efektif dan memudahkan dalam pencarian data serta pembuatan laporan.

Wawancara dilakukan kepada pihak-pihak yang terkait untuk mendapatkan data-data pendukung yang digunakan dalam pembuatan sistem pengelolaan arsip surat masuk dan surat keluar. Dari data-data yang diperoleh akan dilakukan pengintegrasian kebutuhan yang ada ke dalam sebuah sistem administrasi pengelolaan arsip surat masuk dan surat keluar berbasis client server. Selain itu informasi yang diperoleh dengan teknologi client server lebih cepat dan tepat. Sistem yang di kembangkan nantinya dapat memberikan kemudahan dalam pencarian data serta pembuatan laporan surat masuk dan surat keluar.

Berdasarkan latar belakang masalah diatas, penulis tertarik untuk membangun sebuah sistem berbasis client server pengelolaan data surat masuk dan surat keluar yang diwujudkan dalam bentuk judul Tugas Akhir, yaitu "Sistem Administrasi Pengelolaan Arsip Surat Masuk dan Surat Keluar Berbasis Client Server (Studi Kasus: SMK Negeri 1 Mandiraja)". Hal lain yang melatarbelakangi penulis membuat sistem client server diantaranya, pernah terjadinya keterlambatan surat yang harusnya segera disampaikan kepada kepala sekolah yang mengakibatkan kepala sekolah tidak menghadiri undangan dari sekolah lain. Dengan memanfaatkan jaringan client server, staf tata usaha sebagai admin dapat langsung meng-upload surat. Kepala sekolah dapat langsung menerima surat tersebut, dan juga dapat melihat dan mencetak laporan tanpa harus meminta ke bagian Tata Usaha, User seperti bagian Waka 
Kurikulum dapat melihat dan mencetak sendiri surat masuk yang mereka terima sehingga akan lebih praktis apabila sewaktu-waktu membutuhkan. Semoga sistem informasi ini bisa berjalan dengan lancar dan mempermudah proses pengelolaan arsip surat masuk dan surat keluar di SMK Negeri 1 Mandiraja.

\section{METODE PENELITIAN}

\subsection{Metode Pengumpulan Data}

a. Pengamatan (Observasi)

Pengamatan langsung atau observasi merupakan teknik pengumpulan data dengan langsung melihat kegiatan yang dilakukan oleh user [4]. Penulis mengamati secara langsung petugas Tata Usaha dalam mencatat surat masuk ke dalam agenda surat masuk dan pembuatan surat keluar serta pencatatannya dalam buku agenda surat keluar.

b. Wawancara

Menurut [5] wawancara merupakan pertemuan dua orang untuk bertukar informasi dan ide melalui tanya jawab, sehingga dapat dikonstruksikan makna dalam suatu topik tertentu. Wawancara dilakukan kepada petugas Tata Usaha SMK Negeri 1 Mandiraja guna mencari informasi mengenai kebutuhan aplikasi sehingga penulis memiliki gambaran yang nantinya menjadi dasar dalam pembuatan sistem administrasi pengelolaan arsip surat masuk dan surat keluar di SMK Negeri 1 Mandiraja.

c. Dokumtasi

Menurut [5] dokumen merupakan catatan peristiwa yang sudah berlalu. Dokumentasi dalam penelitian ini didapatkan data-data berupa laporan surat masuk dan surat keluar satu tahun terakhir.

d. Studi Pustaka

Menurut Yakub [6] Studi pustaka dilakukan untuk mencari landasan teori dari berbagai literatur yang berkaitan dengan masalah penelitian. Studi pustaka ini dilakukan dengan membaca buku-buku perpustakaan, panduan, serta literatur lain yang berkaitan dengan bidang penelitian. Pengumpulan data dilakukan dengan cara mempelajari referensi dan penelitian yang terkait dengan sistem yang dibuat, yaitu buku, jurnal dan penelitian sebelumnya yang berkaitan dengan sistem adminitrasi surat masuk dan keluar.

\subsection{Metode Pengembangan Sistem}

Dalam perancangan sistem pada penelitian ini, metode pengembangan sistem yang digunakan adalah Extreme Programming (XP). Adapun tahapan-tahapan yang harus dilalui dalam metode Agile proses Extreme Programming sebagai berikut: 


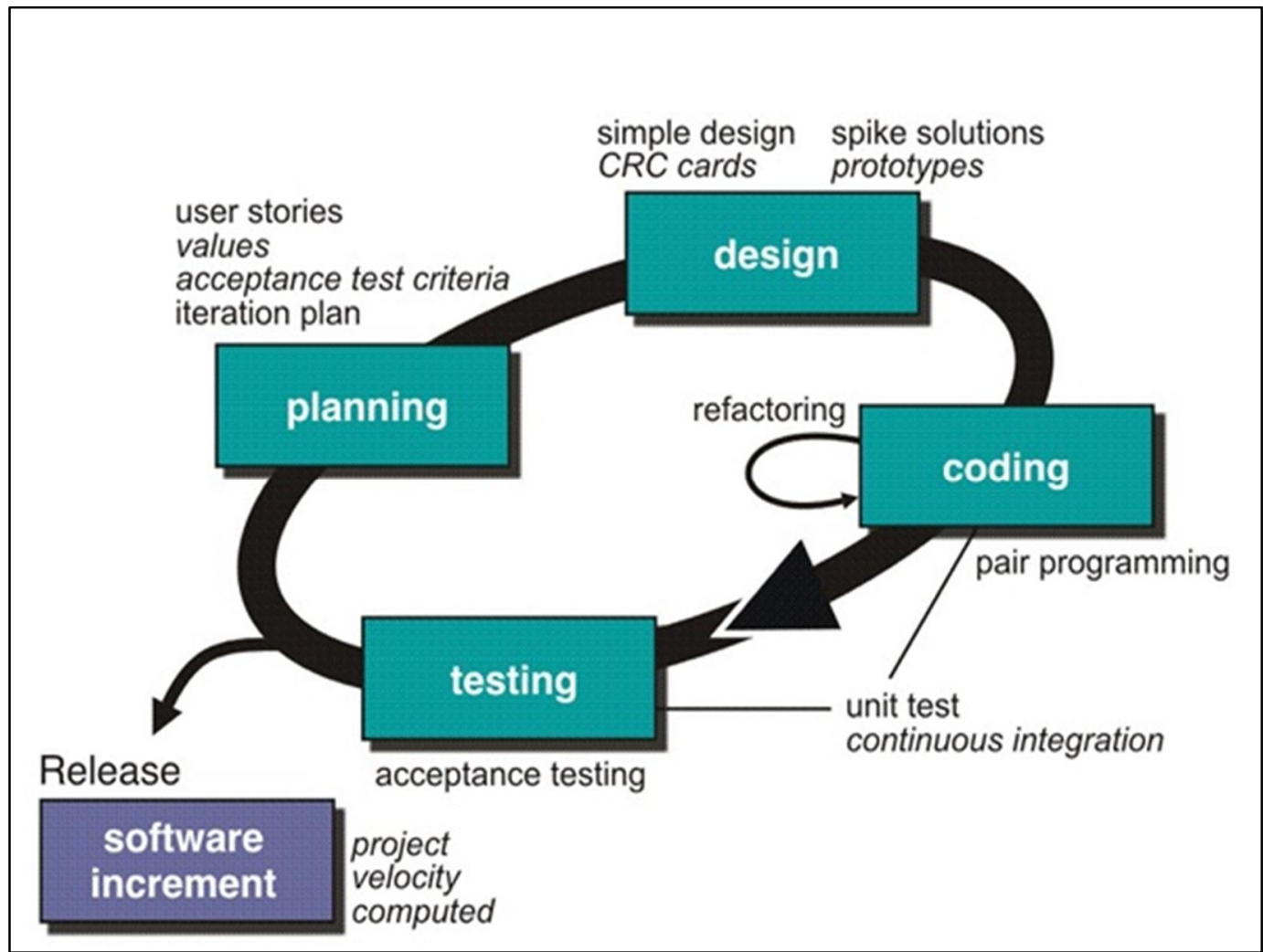

Gambar 1. Tahapan-tahapan Extreme Programming

Berikut merupakan tahap-tahapan yang harus dilalui metode Extreme Programming menurut [7] dalam penelitian:

a. Perencanaan (Planning)

Tahap Planning atau Perencanaan dilakukan dengan mengumpulkan kebutuhan untuk memahami konteks bisnis pada sistem administrasi pengelolaan arsip surat masuk dan surat keluar yang akan dibuat dan untuk mendapatkan pandangan output sistem administrasi pengelolaan surat masuk dan surat keluar serta fitur dan fungsi utamanya.

b. Perancangan (Design)

Tahap design dilakukan dengan pembuatan desain sederhana mengenai pengembangan sistem administrasi pengelolaan surat masuk dan surat keluar yang kemudian dilakukan pembuatan class diagram.

c. Pengkodean (Coding)

Tahap Coding dilakukan dengan melakukan pengkodean dari pengembangan sistem administrasi pengelolaan arsip surat masuk dan surat keluar. Pengkodean Sistem client server menggunakan framework Codeigniter dan didukung dengan database MySQL.

d. Pengujian (Testing)

Tahap testing dilakukan dengan melakukan pengujian terhadap pengkodean (coding) pada sistem dengan menggunakan unit test yaitu dengan pengujian blackbox testing. 


\section{HASIL DAN PEMBAHASAN}

Sistem Arsip Surat Masuk dan Surat Keluar SMK Negeri 1 Mandiraja adalah suatu sistem administrasi pengarsipan surat pada SMK Negeri 1 Mandiraja yang harus disimpan/diarsipkan. Semakin lama surat-surat yang harus diarsipkan semakin banyak dan beragam jenisnya. Oleh karena itu diperlukan manajemen kearsipan yang baik, cepat dan efisien. Sistem informasi pengelolaan arsip surat ini dikembangkan menggunakan metode Extreme Programming. Dalam pengembangan sistem dengan metode Extreme Programming terdapat 4 tahapan yaitu planning, design, coding, dan testing.

\subsection{Perencanaan}

Pada Tahap ini peneliti melakukan wawancara untuk memperoleh gambaran sistem manual pengelolaan arsip surat masuk dan surat keluar yang telah diterapkan di SMK Negeri 1 Mandiraja. Kemudian peneliti melakukan identifikasi atau analisa kebutuhan untuk membangun sistem administrasi surat masuk dan surat keluar untuk selanjutnya dijabarkan identifikasi kebutuhan fungsional dan non fungsional berdasarkan hasil dari teknik perolehan data yang telah dilakukan yang terkait dalam pembuatan sistem administrasi arsip surat masuk dan surat keluar.

\subsection{Perancangan}

Untuk perancangan sistem dalam penelitian ini menggunakan bahasa pemodelan Unified Modeling Language (UML) yang menjadi standar visualisasi, perancangan, serta pendokumentasian sebuah sistem yang bersifat object oriented. Pada tahap pemodelan dengan UML terdiri dari macam-macam diagram UML antara lain Use Case Diagram, Activity Diagram, Sequence Diagram, dan Class Diagram.

a. Use Case Diagram

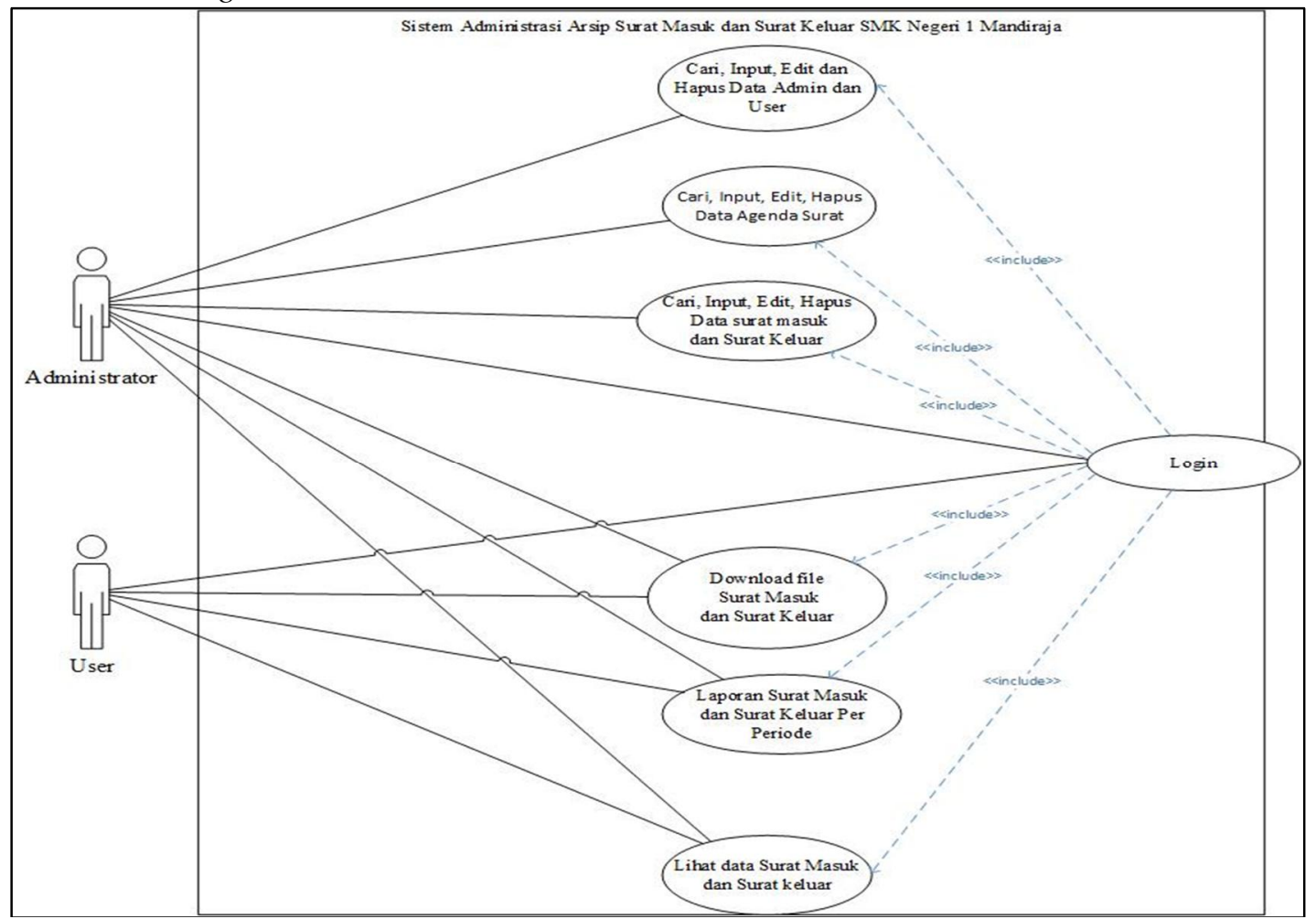

Gambar 2. Use Case Diagram 
Gambar diatas menjelaskan proses alur aktivitas yang ada di sistem administrasi arsip surat masuk dan surat keluar SMK Negeri 1 Mandiraja yang memiliki 2 aktor yaitu administrator dan user. Semua aktor mempunyai aktivitas login sebelum dapat melakukan aktivitas lainnya, administrator dapat melakukan cari, input, edit, hapus data admin dan user selain itu administrator dapat mengelola data agenda surat masuk dan surat keluar seperti cari, input, edit dan hapus data. Administrator juga dapat melakukan download surat masuk dan surat keluar, membuat laporan agenda surat masuk dan surat keluar dengan filter periode tertentu dan lihat data surat masuk dan surat keluar. User (pengguna) dalam sistem pengelolaan arsip surat masuk dan surat keluar SMK Negeri 1 Mandiraja hanya dapat melakukan lihat data surat masuk dan surat keluar, membuat laporan rekapitulasi agenda surat masuk dan surat keluar dengan filter periode tertentu dan download file surat masuk dan surat keluar.

b. Sequence Diagram

Sequence diagram digunakan untuk menggambarkan interaksi antar objek di dalam dan di sekitar sistem (termasuk pengguna, display dan sebagainya) berupa message yang digambarkan terhadap waktu.

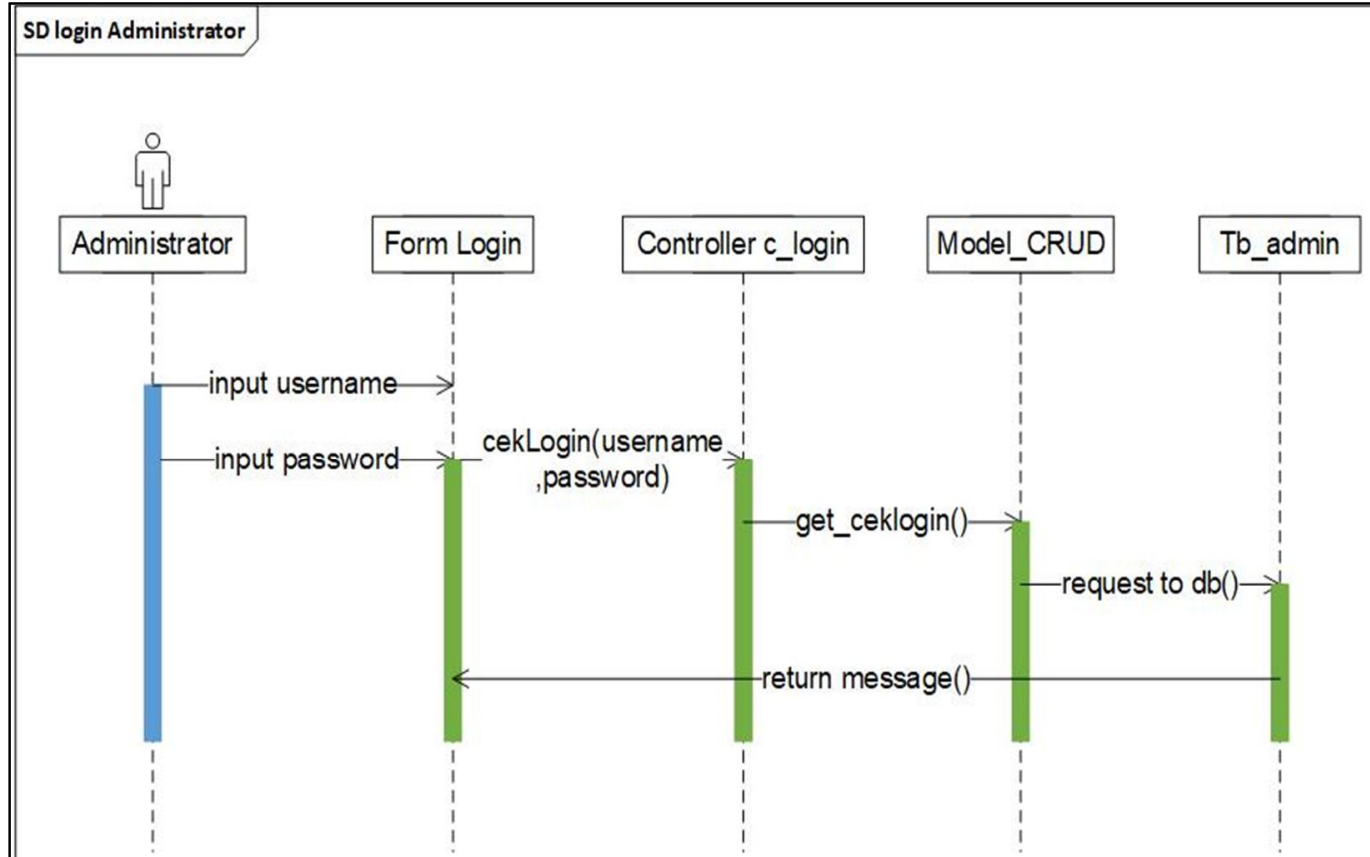

Gambar 3. Sequence Diagram Login Administrator

Gambar di atas menerangkan proses administrator mengakses form login dengan memasukkan username dan password. Form login mengirim data username dan password menuju controller c_login. Controller c_login menggunakan function cekLogin dari model CRUD untuk mengecek apakah username dan password yang diinputkan sesuai, kemudian model CRUD melakukan request data ke tb_admin, kemudian tb_admin melalui system memberikan nilai kembali kepada administrator.

c. Activity Diagram

Activity diagram atau diagram aktivitas menggambarkan workflow (aliran kerja) atau aktivitas dari sebuah sistem atau proses bisnis. Berikut ini akan digambarkan activity diagram dari use case yang ada: 


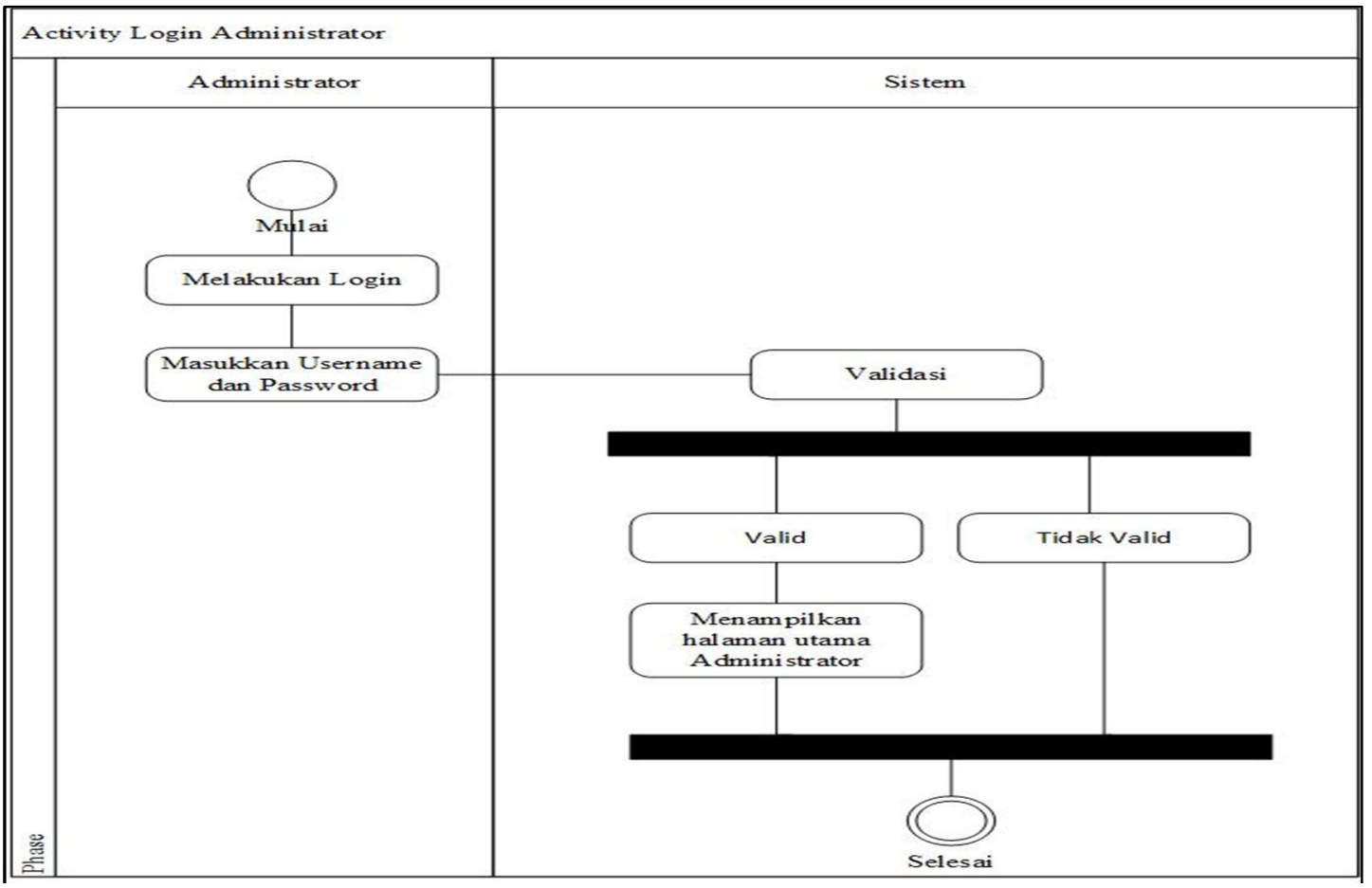

Gambar 4. Activity Diagram Login Administrator

Gambar di atas menjelaskan proses aktivitas administrator melakukan login agar dapat mengakses halaman administrator. Proses yang dilalui adalah administrator melakukan login, kemudian memasukkan username dan password, selanjutnya sistem akan melakukan validasi terhadap username dan password yang di masukkan. Jika username dan password valid, maka administrator dapat masuk ke halaman utama administrator, jika tidak valid maka administrator tidak dapat masuk.

d. Class Diagram

Class Diagram digunakan untuk menampilkan kelas-kelas dan paket-paket di dalam sistem dan memberikan gambaran sistem secara statis dan relasi antar mereka. Berikut adalah class diagram pada sistem administrasi pengelolaan arsip surat masuk dan surat keluar SMK Negeri 1 Mandiraja: 


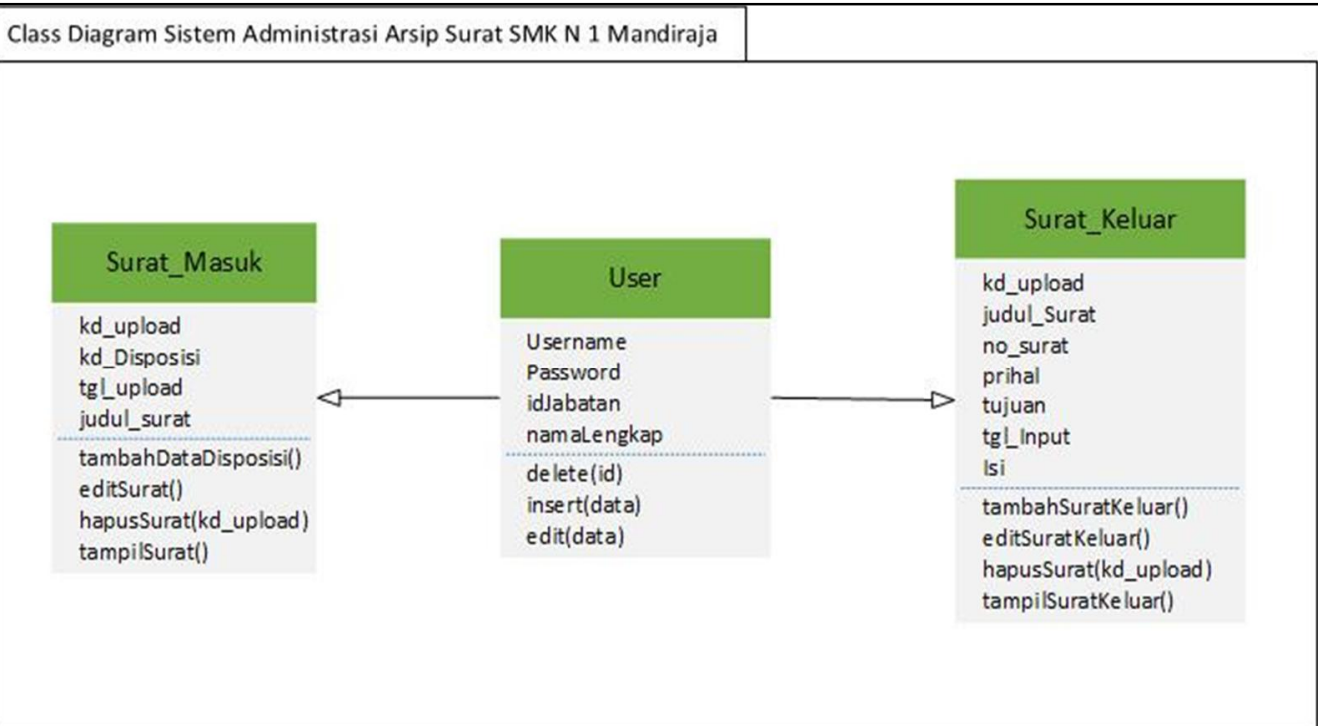

Gambar 5. Class Diagram

\subsection{Pengkodean}

Tahap pengkodean merupakan translasi dari desain yang telah di buat kedalam kode program komputer. Berikut ini Sistem Administrasi Pengelolaan Arsip surat masuk dan surat keluar di SMK Negeri 1 Mandiraja:

a. Halaman Login Administrator

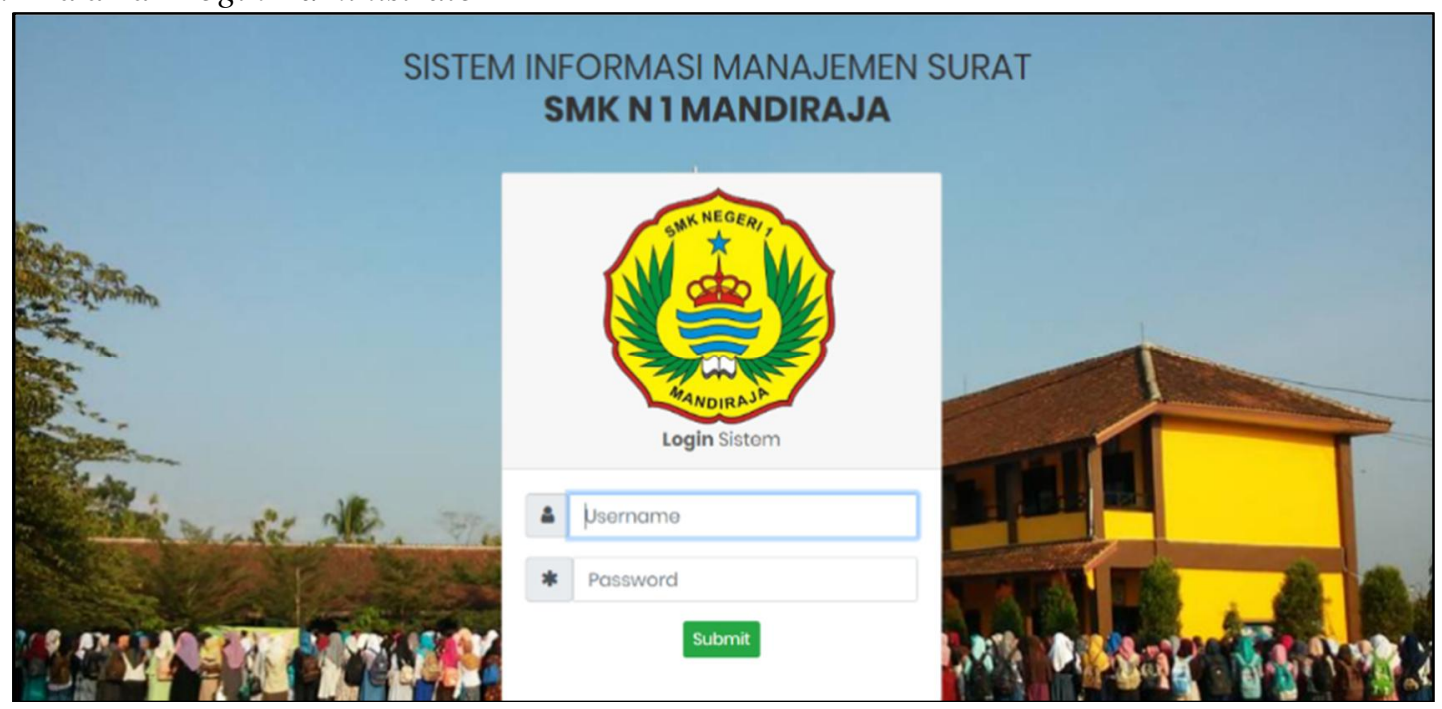

Gambar 6. Halaman Login Administrator

Gambar di atas merupakan tampilan halaman login administrator. Administrator dapat melakukan login dengan memasukkan username dan password pada Form input yang tersedia. 
b. Halaman Dashboard Administrator

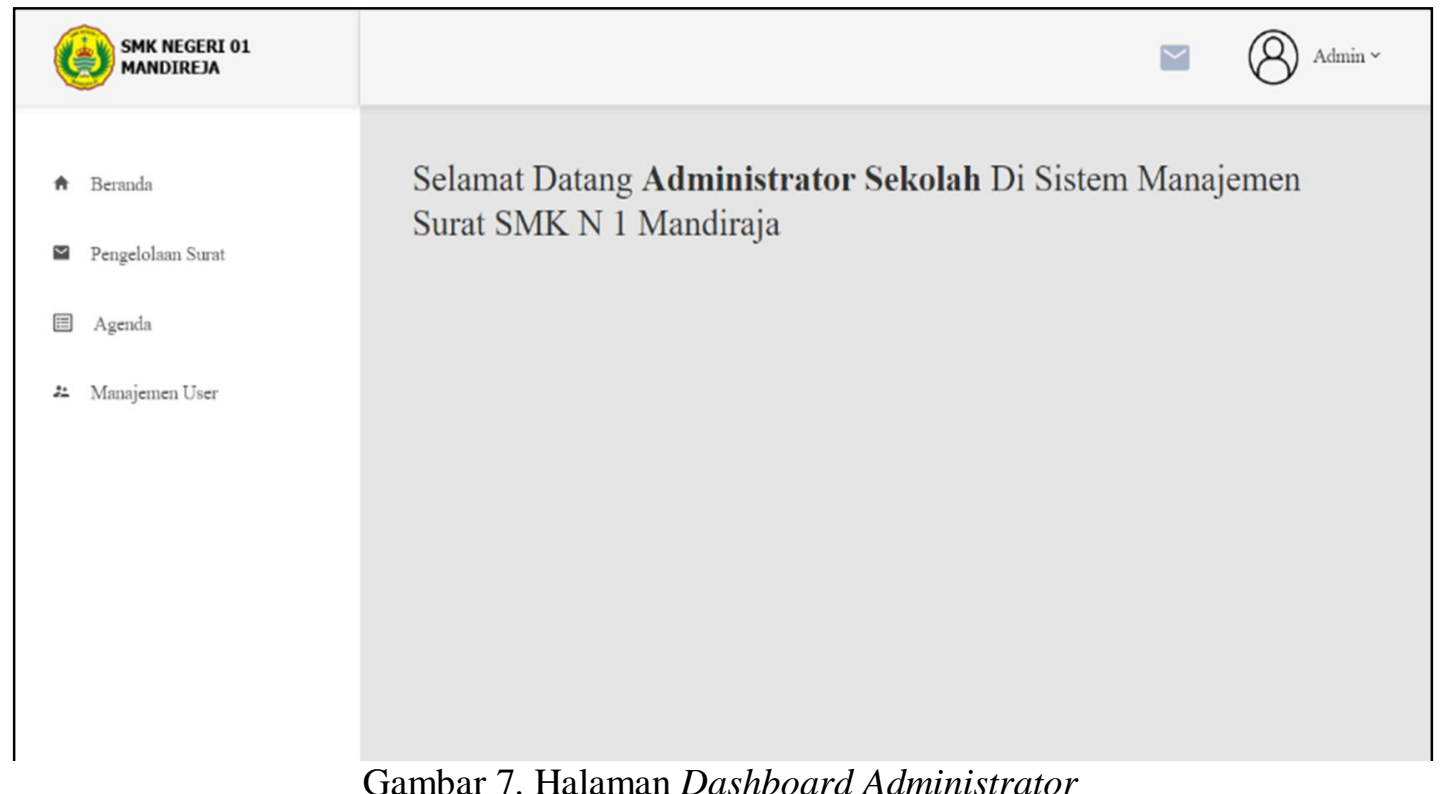

Halaman dashboard merupakan halaman utama administrator. Pada halaman ini terdapat beberapa menu yang dapat digunakan untuk mengelola data diantaranya menu pengelolaan surat, agenda, dan manajemen user.

c. Halaman Pengelolaan Surat Masuk

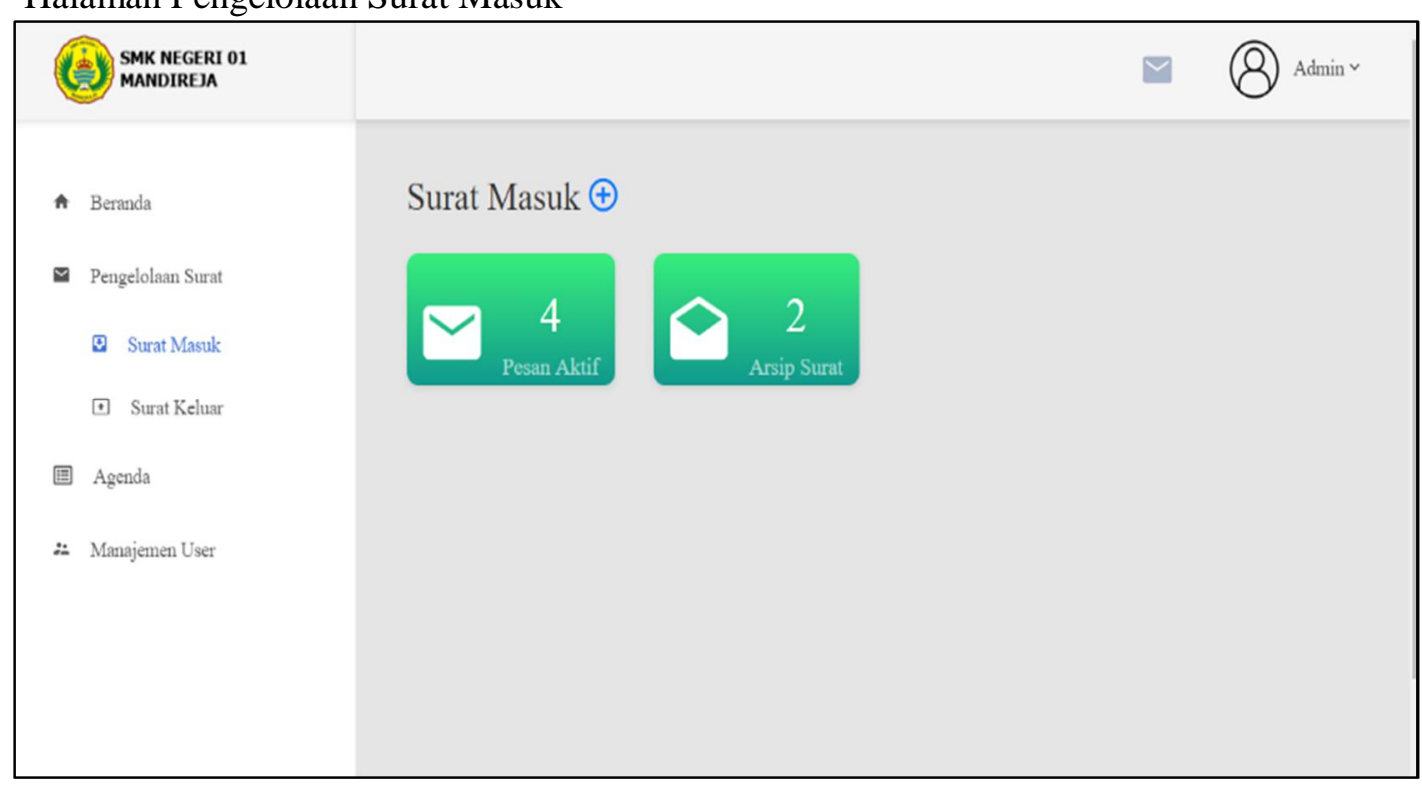

Gambar 8. Halaman Pengelolaan Surat Masuk

Pada halaman ini administrator dapat melakukan pengelolaan surat masuk seperti input surat masuk. 
d. Halaman Disposisi

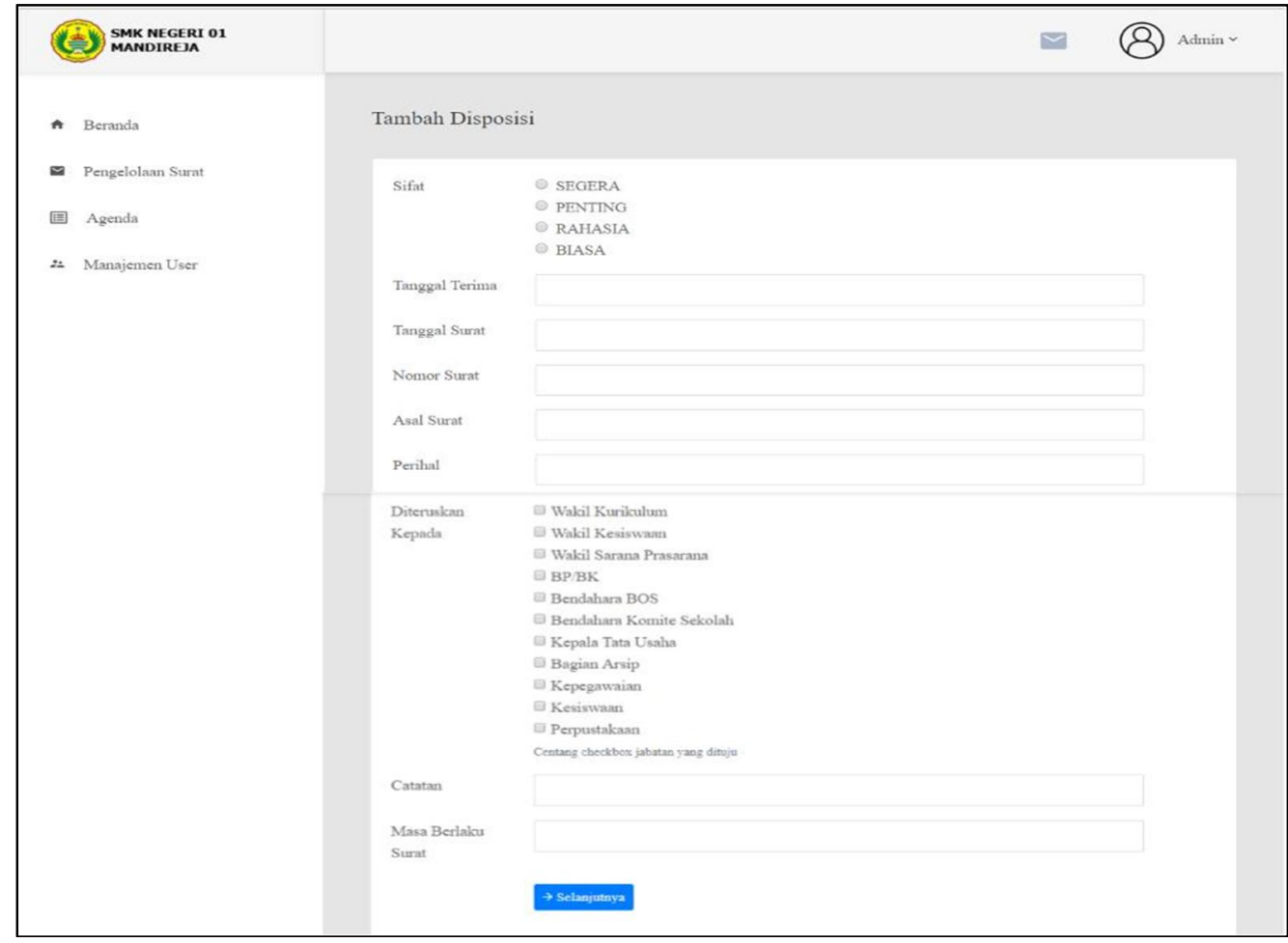

Gambar 9. Halaman Disposisi

Pada halaman ini administrator dapat melakukan tambah disposisi seperti memilih tujuan disposisi.

e. Halaman Manajemen User

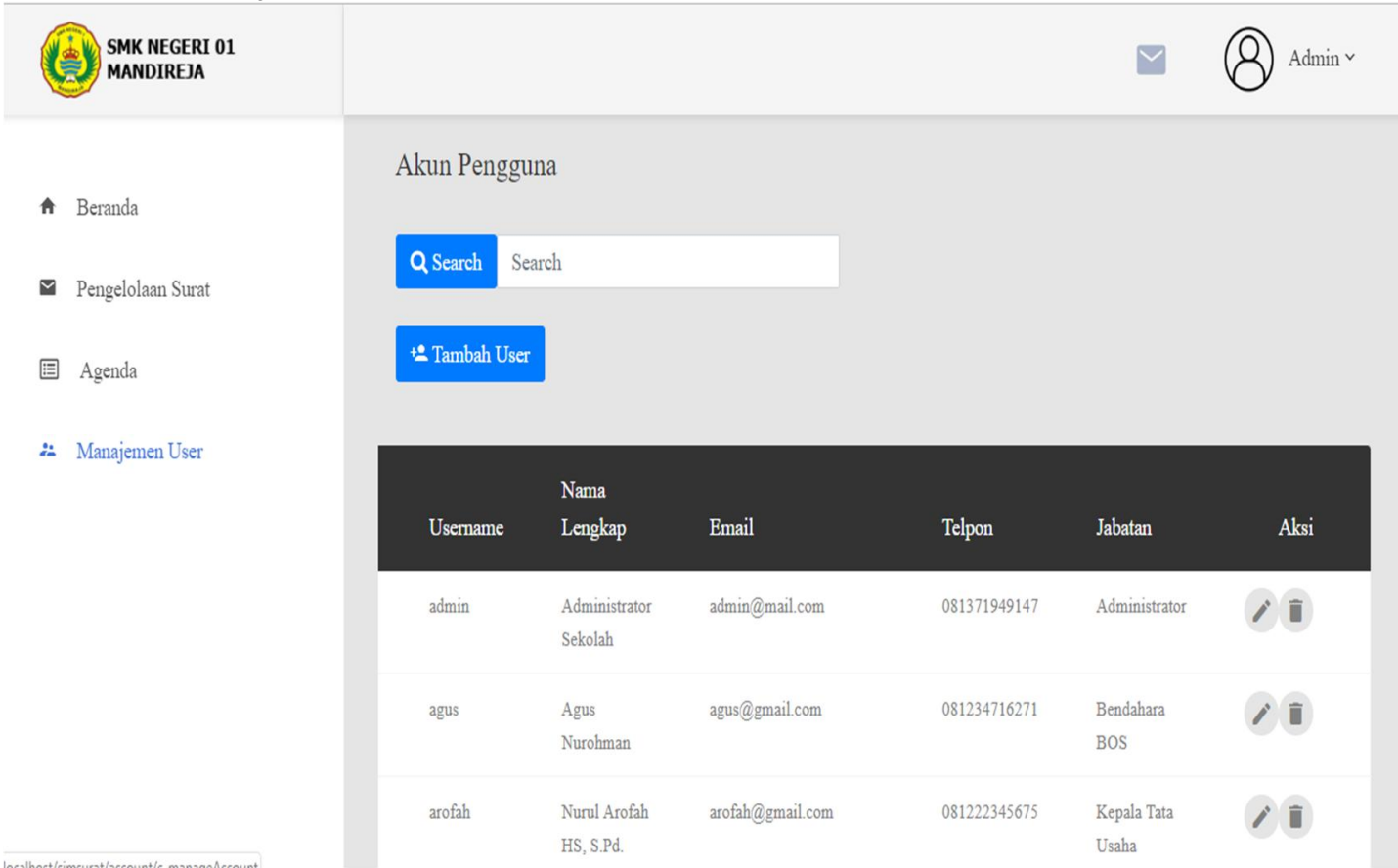

Gambar 10. Halaman Manajemen User 
ada halaman ini administrator dapat melakukan CRUD data data user dan untuk administrator hanya dapat di edit.

f. Halaman Login User

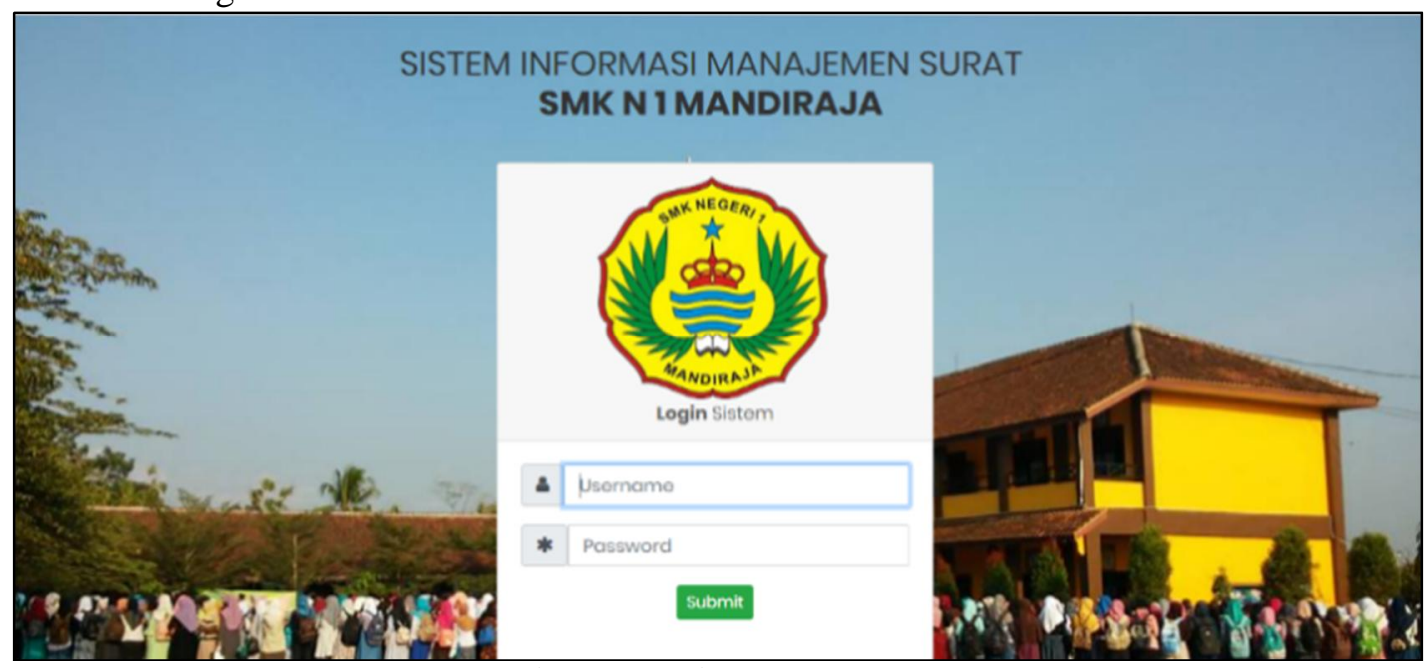

Gambar 11. Halaman Login User

Gambar di atas merupakan tampilan halaman login user. User dapat melakukan login dengan memasukkan username dan password pada Form input yang tersedia.

g. Halaman Dashboard User

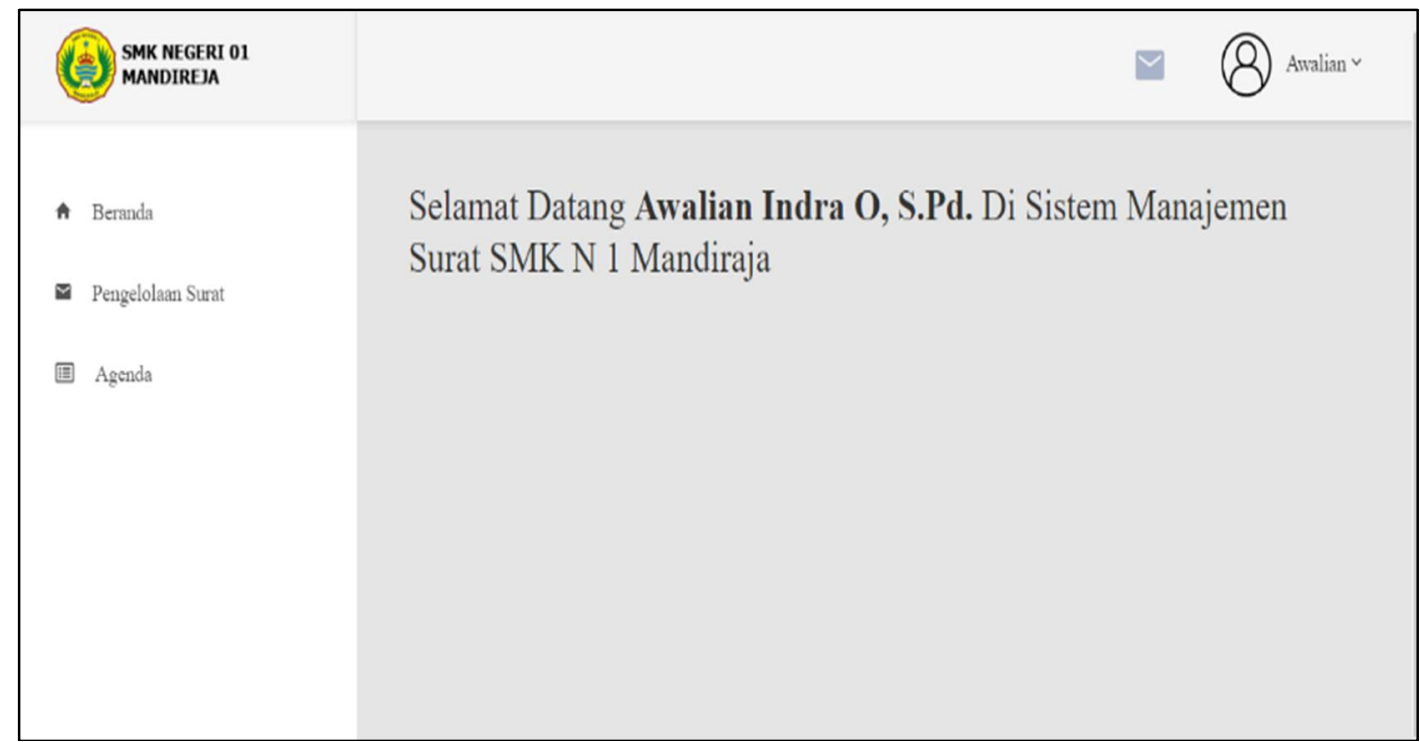

\section{Gambar 12. Halaman Dashboard User}

Halaman dashboard merupakan halaman utama user. Pada halaman ini terdapat beberapa menu yang dapat digunakan untuk mengelola data diantaranya menu pengelolaan surat dan agenda.

\subsection{Pengujian}

Pengujian dilakukan dengan tujuan mengetahui bahwa komponen sistem telah berjalan dengan baik. Tujuan lain dari proses pengujian yaitu untuk mengetahui apakah aplikasi dapat memudahkan dalam proses pengelolaan arsip surat masuk dan surat keluar. Acceptance testing 
dilakukan untuk menentukan apakah sistem yang dibangun telah memenuhi kriteria penerimaan serta menentukan apakah sistem dapat diterima atau tidak. Unit testing pada sistem pengelolaan arsip surat masuk dan keluar SMK Negeri 1 Mandiraja menggunkan pengujian blackbox. Pengujian blackbox testing merupakan pengujian program berdasarkan fungsi dari program. Tujuan dari pengujian blackbox testing adalah untuk menemukan kesalahan fungsi pada program.

\section{KESIMPULAN}

Berdasarkan hasil yang didapatkan dari proses analisis dan hasil, maka penelitian tentang pengelolaan arsip surat masuk dan surat keluar di SMK Negeri 1 Mandiraja dapat ditarik beberapa kesimpulan diantaranya

1. Fitur utama sistem administrasi pengelolaan surat masuk dan surat keluar yang diterapkan di SMK Negeri 1 Mandiraja adalah surat masuk, surat keluar, agenda surat dan disposisi surat.

2. Aplikasi client server sistem administrasi pengelolaan surat masuk dan surat keluar yang ada di SMK Negeri 1 Mandiraja meliputi sistem untuk guru dan staf.

3. Dari pengujian yang dilakukan dengan menggunakan metode blackbox pada sistem informasi pengarsipan surat masuk dan keluar di SMK Negeri 1 Mandiraja didapatkan sistem berjalan dengan baik atau sesuai yang diharapkan.

\section{SARAN}

Saran yang dapat di pertimbangkan untuk mendukung sistem pengelolaan arsip surat masuk dan surat keluar di SMK Negeri 1 Mandiraja antara lain:

1. Dengan berkembangnya teknologi Android, penulis berharap akan ada pengembangan lanjutan untuk aplikasi ini menjadi Aplikasi berbasis Android.

2. Untuk implementasi model perlu adanya respon langsung dari para guru dan staf terhadap proses-proses dalam sistem, khususnya berkaitan dengan informasi yang mereka dapatkan dan informasi lain yang dibutuhkan, sehingga model sistem pengelolaan arsip surat ini dapat dikembangkan lebih lanjut untuk mendapatkan aplikasi yang optimal.

\section{UCAPAN TERIMA KASIH}

Penulis mengucapkan terima kasih kepada Universitas Amikom Purwokerto yang telah memberi dukungan terhadap penelitian ini.

\section{DAFTAR PUSTAKA}

[1] Peraturan Menteri Pendidikan dan Kebudayaan Republik Indonesia Nomor 74 Tahun 2015 Tentang Pedoman Tata Naskah Dinas di Lingkungan Kementrian Pendidikan.

[2] Sapto, M. 2014, Bangun Sistem Informasi Disposisi Surat Berbasis Web (Studi Kasus Kementrian Pekerjaan Umum), Indonesian Journal on Networking and Security 25-32. 
[3] Yuslianto, Eko. 2015, Aplikasi Sistem Kearsipan Surat - surat Dinas Menggunakan Elektronik Arsip (E-ARSIP) di Sekretariat Daerah Provinsi Jawa Tengah, Skripsi Universitas Negeri Semarang.

[4] Sutabri, Tata. 2012, Analisis Sistem Informasi, Andi Offset, Yogyakarta.

[5] Sugiyono. 2012, Metode Penelitian Kuantitatif, Kualitatif, dan $R \&$ $\&$, Alfabeta, Bandung.

[6] Yakub. 2012, Pengantar Sistem Informasi, Graha Ilmu, Yogyakarta.

[7] Pressman, R. S. 2012, Rekayasa Perangkat Lunak, jilid, Andi, Yogyakarta. 